\title{
E167K polymorphism of TM6SF2 gene affects cell cycle of hepatocellular carcinoma cell HEPA 1-6
}

Shuixian Du ${ }^{1,2^{*}}$, Linlin Lu ${ }^{2,3}$, Yingxia Miao ${ }^{1,2}$, Wenwen Jin ${ }^{2}$, Changfei $\mathrm{Li}^{1,2}$, Yongning Xin ${ }^{1,2,3^{*}}$ and Shiying Xuan ${ }^{1,2,3}$

\begin{abstract}
Background: Some studties reported that the polymorphism of TM6SF2 gene E167K affects the occurrence and the progression of hepatocytes carcinoma (hepatocellular, HCC). In oeder to investigate the effects of the polymorphism of TM6SF2 gene E167K in the pathogenesis of HCC, we explored its influence on the cell cycle in hepatocellular carcinoma cell HEPA1-6.
\end{abstract}

Methods: HEPA 1-6 cells which could respectively overexpress TM6SF2 wild type and E167K variant were cultured and HEPA 1-6 cells with zero load plasmids were used as matched control. Flow cytometry was used to detect the cell cycles of these 3 type of HEPA 1-6 cells. Realtime fluores-cence quantitative PCR and western blot were used to analyzed the expression of regulatory factors (Cyclin D1、p53、P16、P27、P21 and Rb) of cell cycle. T-test was used in statistical analysis.

Results: Cell cycle phase distribution was presented by the proportion of cells in each phases (\%). Compared with the control group, the cell cycle phase distribution ( $\mathrm{G}_{1}$ phase $57.36 \pm 0.21 \%, \mathrm{G}_{2} / \mathrm{M}$ phase $25.61 \pm 0.36 \%, \mathrm{~S}$ phases $19.31 \pm 0.25 \%)$ had no differences in wild type group $\left(G_{1}\right.$ phase $57.63 \pm 0.28 \%, G_{2} / M$ phase $25.77 \pm 0.51 \%, S$ phases $19.54 \pm 0.25 \% ; P<0.05)$. Between variant type group and wild type group, $G_{1}$ phase was significantly decreased (variant type group $G_{1}$ phase $36.26 \pm 0.31 \%, P<0.05$ ), $S$ phase and $G_{2} / M$ phase were increased(variant type group $S$ phase $28.41 \pm 0.31 \%, P<0.05 ; G_{2} / M$ phase $\left.35.23 \pm 0.14 \%, P<0.05\right)$, respectively. Compared with control group,the relative expression of CyclinD1、P53 and Rb mRNA in variant type group was significantly upregulated $(2.03 \pm 0.01$ VS $1.04 \pm 0.06,1.88 \pm 0.05$ VS $1.37 \pm 0.03,1.29 \pm 0.06$ VS $1.15 \pm 0.03, P<0.05)$ and P27 mRNA in variant type group was significantly downregulated ( $0.56 \pm 0.02$ VS $0.85 \pm 0.05, P<0.05)$.

Compared with wild type group, the relative expression of CyclinD1、P53 and Rb mRNA in variant type group was significantly upregulated (wild type group $1.00 \pm 0.00,1.48 \pm 0.09,1.18 \pm 0.01, P<0.05$ ) and P27 mRNA in variant type group was significantly downregulated (variant type group $0.82 \pm 0.05, P<0.05$ ). There was no statistical significance between wild type group and control group $(P>0.05)$. P16 and P21 expression showed no statistical sigtfificance in any of these three groups $(P>0.05)$.

Conclusion: E167K polymorphism of TM6SF2 gene affects cell cycles of HEPA1-6 cells via up-regulating CyclinD1、P53 and Rb and down-regulating P27.

Keywords: Hepatocellular carcinoma cell (HCC), Cell cycle, TM6SF2 E167K polymorphism, Western blot, Pcr

\footnotetext{
* Correspondence: 15866813623@163.com; xinyongning1@163.com

${ }^{1}$ Medical College of Qingdao University, Qingdao 266071, China

Full list of author information is available at the end of the article
}

(c) The Author(s). 2017 Open Access This article is distributed under the terms of the Creative Commons Attribution 4.0 International License (http://creativecommons.org/licenses/by/4.0/), which permits unrestricted use, distribution, and reproduction in any medium, provided you give appropriate credit to the original author(s) and the source, provide a link to the Creative Commons license, and indicate if changes were made. The Creative Commons Public Domain Dedication waiver (http://creativecommons.org/publicdomain/zero/1.0/) applies to the data made available in this article, unless otherwise stated. 


\section{Background}

The Strictly cell cycle is the guarantee of proliferation and division, which is very important for maintaining the normal function of the organism. A key function of the cell cycle is to ensure accurate replication and segregation of the genome, because errors in genetic transmission can cause mutations and chromosomal rearrangements that may lead to cell death or disease [1]. Many studies have reported that deregulated cell proliferation and suppressed cell death together provide the underlying platform for neoplastic progression [2-4]. Exploring the changes of cell cycle, which has the great significance to reveal the pathogenesis of the disease. Many studies have reported that the transmembrane 6 superfamily member 2 (TM6SF2) is one of the most important genes of lipid metabolism in the liver and the E167K polymorphism can independently lead to liver fat accumulation, which has an important role in chronic liver disease [5-7]. While some studies reported that the polymorphism of E167K affects the occurrence and the progression of hepatocytes Carcinoma (hepatocellular, HCC) $[5,8,9]$. In order to investigate the effects of the polymorphism of TM6SF2 gene E167K in then pathogenesis of HCC, we explored its influence on the cell cycle in hepatocellular carcinoma cell HEPA 1-6.

In our study, HEPA 1-6 cells which could respectively overexpress TM6SF2 wild type and E167K variant were cultured and HEPA 1-6 cells with zero load plasmids were used as matched control. To explore the cell cycle of HEPA 1-6 cells affected by E167K polymorphism of TM6SF2 gene and the possible mechanisms.

\section{Methods}

\section{Culture of HEPA 1-6 cell lines}

The HEPA 1-6 cell lines were cultured in Dulbecco's Modified Eagle's Medium (DMEM) medium containing $100 \mathrm{U} / \mathrm{mL}$ penicillin, 10\% fetal bovine serum (FBS; Hyclone, USA) and $100 \mu \mathrm{g} / \mathrm{mL}$ streptomycin (Gibco ${ }^{\circ}$, USA), and incubated at temperature $37^{\circ} \mathrm{C}$ in a humidified atmosphere with $5 \% \mathrm{CO} 2$. The cells were treated at the time of approximately $80 \%$ confluence.

\section{Construction of Lentiviral vectors}

The present study had three groups, including TM6SF2 wild type, TM6SF2 variant type and zero load plasmids as matched control. The lentiviral plasmids (Shanghai Genechem Co., LTD) transfected into $293 \mathrm{~T}$ cells, after $24 \mathrm{~h}$ culture in DMEM with 10\% FBS. $293 \mathrm{~T}$ cells were incubated with transfection complexes (expression plasmid, packaging plasmid and transfection reagent) for 48-72 $\mathrm{h}$. We then concentrated the lentivirus and transfected it into HEPA 1-6 cells. The success of the transfection process was validated by performing western blot, real time-polymerase chain reaction (RT-PCR) as well as the percentage of HEPA 1-6 cells with green fluorescent protein (GFP).

\section{Biochemical indicator assay}

Cyclin D1、p53、P16、P27、P21 and Rb monoclonal antibody were purchased from the Biotechnology Corporation, USA. The primer of Cyclin D1、p53、P16、P27、P21 and $\mathrm{Rb}$ were designed by Invitrogen Corporation, USA. While the primer of $\beta$-actin was synthesized by Nanjing Kingsy Biotechnology Co., ltd.

\section{Cell cycle determination}

The logarithmic growth phase of cells were digested into suspension in a centrifuge tube of $15 \mathrm{ml}$, centrifugaled at room temperature for $5 \mathrm{~min}$ with $800 \mathrm{r} / \mathrm{min}$, centrifugaled and washed 2 times repeatly with PBS, and then fixed at temperature $4{ }^{\circ} \mathrm{C}$ with $2 \mathrm{ml} 70 \%$ absolute alcoholo vernight.

The fixed cells were centrifugaled at room temperature for $5 \mathrm{~min}$ with $800 \mathrm{r} / \mathrm{min}$ and then retained $0.5 \mathrm{ml} \mathrm{PBS}$ to percuss the cells into suspension, and then add $1 \mathrm{mg} / \mathrm{ml}$ PI and RNase A, and water bath at temperature $37^{\circ} \mathrm{C}$ for $30 \mathrm{~min}$. Flow cytometry was used to detect the cell cycle.

\section{Western blotting}

Total protein of the HEPA 1-6 cells was extracted by RIPA buffer (Sigma-Aldrich, USA). Bradford method was performed to determine the protein concentration following the manufacturer's protocols, and proteins were frozen at $-70{ }^{\circ} \mathrm{C}$ until analysis. Antibodies against Cyclin D1(JIANGSU KEYGEN BIOTECH. CO., LTD, KG22272)、p53(JIANGSU KEYGEN BIOTECH. CO., LTD, KG22606)、P16(JIANGSU KEYGEN BIOTECH. CO., LTD, KG22602)、P27(JIANGSU KEYGEN BIOTECH. CO., LTD, KG30242)、P21(JIANGSU KEYGEN BIOTECH. CO., LTD, KG30240)、Rb(JIANGSU KEYGEN BIOTECH. CO., LTD, KG21109) and GAPDH (KGAA002) were used. The expression level of Cyclin D1 or the other protein was normalized relative to the corresponding GAPDH (endogenous reference) level in each lane. Images of Western Blotting were analyzed using Gel-Pro Analyzer Version 4.5 Software (Media Cybernetics, USA).

\section{Quantitative real time PCR}

Total RNA was isolated from the HEPA 1-6 cells using Trizol reagent (Invitrogen: 15,596-026, USA) following the manufacturer's protocols. Complementary DNA (cDNA) synthesis was performed using the RevertAid First Strand cDNA Synthesis Kit (Thermo Fisher: K1622, USA).

The primers for PCR amplification of the fragments containing Cyclin D1、p53、P16、P27、P21 and Rb were synthesized by Nanjing Sipu Kim Technology Co. 
Ltd.: 5- CAGATCATCCGCAAACACGC -3 and 5- AA GTTGTTGGGGCTCCTCAG -3 for Cyclin D1, 5-CTG GATTGGCAGCCAGACT-3 and 5- GCTCGACGCTAG GATCTGAC-3 for P53, 5- TGTGCCACACATCTTT GACCT-3 and 5- AGGACCTTCGGTGACTGATGA-3 for P16, 5- CCCTGAACGGAGCTGAAGTC-3 and 5TAACCGCGCAGCAGATAGTC-3 for P27, 5- CGTTC ACAGGTGTTTCTGCG-3 and 5- CATTAGCGCATCA CAGTCGC-3 for P21, 5- TGCAGTATGCTTCCACC AGG-3 and 5- TGTTGGTGTTGGCAGACCTT-3 for Rb, 5-CTCCATCCTGGCCTCGCTGT-3 and 5-GCTGT CACCTTCACCGTTCC- 3 for $\beta$-actin. The PCR amplification profile was as follows: pre-denaturation at $95{ }^{\circ} \mathrm{C}$ for $10 \mathrm{~min}, 35$ cycles, denaturation at $95^{\circ} \mathrm{C}$ for $15 \mathrm{~s}$, annealing at $58{ }^{\circ} \mathrm{C}$ for $60 \mathrm{~s}$, extending at $72{ }^{\circ} \mathrm{C}$ for $30 \mathrm{~s}$, and finally extending at $72{ }^{\circ} \mathrm{C}$ for $10 \mathrm{~min}$ to terminate the reaction. We used the comparative threshold cycle (CT) method to obtain the above genes [10].

\section{Statistical analysis}

Data are expressed as the mean \pm standard deviation (S.D.) and T-test was used in statistical analysis. These statistical analyses were performed using SPSS 17.0 statistical software (SPSS Inc., Chicago, IL, USA). $P<0.05$ were considered statistically significant.

\section{Results}

Constructed HEPA 1-6 cell lines with overexpress TM6SF2 successfully

The lentiviral plasmids transfected into HEPA 1-6 after $48 \mathrm{~h}$, the positive rate of GFP >95\% was observed, which prompted we have constructed stable strains successfully.

\section{Detected cell cycle by flow cytometry}

Table 1 showed the proportion of cells in each cell cycle stage of the three groups. Compared with the wild type group, the cell cycle phase distribution $\left(\mathrm{G}_{1}, \mathrm{~S}\right.$ and $\left.\mathrm{G}_{2} / \mathrm{M}\right)$ had no differences in control group ( $t$ was $1 / 336,1.127$, 0.444 , respectively, $P$ all $>0.05$.); Compared with the wild type group and the control group, $G_{1}$ phase was significantly decreased and $S$ phase, $G_{2} / M$ phase were increased in variant type group $(p$ all $<0.001$.).

\section{Detection of Cyclin D1、p53、P16、P27、P21 and Rb} protein expression by western blot

Compared with control group and wild type group,the relative expression of CyclinD1、P53 and $\mathrm{Rb}$ in variant type group was significantly upregulated and P27 mRNA in variant type group was significantly downregulated $(P<0.05)$, there was no statistical significance between wild type group and control group $(P>0.05)$. P16 and P21 expression showed no statistical sigtfificance in any of these three groups $(P>0.05)$. (Fig. 1$)$.
Table 1 Comparison of the percentage of cell cycle in three groups $(n=3)$

\begin{tabular}{llll}
\hline groups & \multicolumn{3}{l}{ Cell cycle stage (\%) } \\
\cline { 2 - 4 } & $\mathrm{G}_{1}$ & $\mathrm{~S}$ & $\mathrm{G}_{2} / \mathrm{M}$ \\
\hline variant type group & $36.26 \pm 0.31$ & $28.41 \pm 0.31$ & $35.23 \pm 0.14$ \\
wild type group & $57.63 \pm 0.28$ & $19.54 \pm 0.25$ & $25.77 \pm 0.51$ \\
the control group & $57.36 \pm 0.21$ & $19.31 \pm 0.25$ & $25.61 \pm 0.36$ \\
t1 & -88.607 & 38.577 & 30.982 \\
p1 & $<0.001$ & $<0.001$ & $<0.001$ \\
t2 & -97.595 & 39.577 & 29.201 \\
p2 & $<0.001$ & $<0.001$ & $<0.001$ \\
t3 & 1.336 & 1.127 & 0.444 \\
p3 & $>0.05$ & $>0.05$ & $>0.05$ \\
\hline
\end{tabular}

$\mathrm{t} 1$ :Between variant type group and wild type group; $\mathrm{t} 2$ : Between variant type group and the control group; t3: Between wild type group and the control group;

Detection of Cyclin D1、p53、P16、P27、P21 and Rb mRNA expression by quantitative real time PCR

Compared with control group, the relative expression of CyclinD1、P53 and Rb mRNA in variant type group was significantly upregulated (t was 28.190, 15.152, $3.615, P$ all $<0.05$ ) and P27 mRNA in variant type group was significantly downregulated (t was 9.328, $P<0.05$ ). Compared with wild type group, the relative expression of CyclinD1、P53 and Rb mRNA in variant type group was significantly upregulated ( $t$ was 178.532, 6.729,

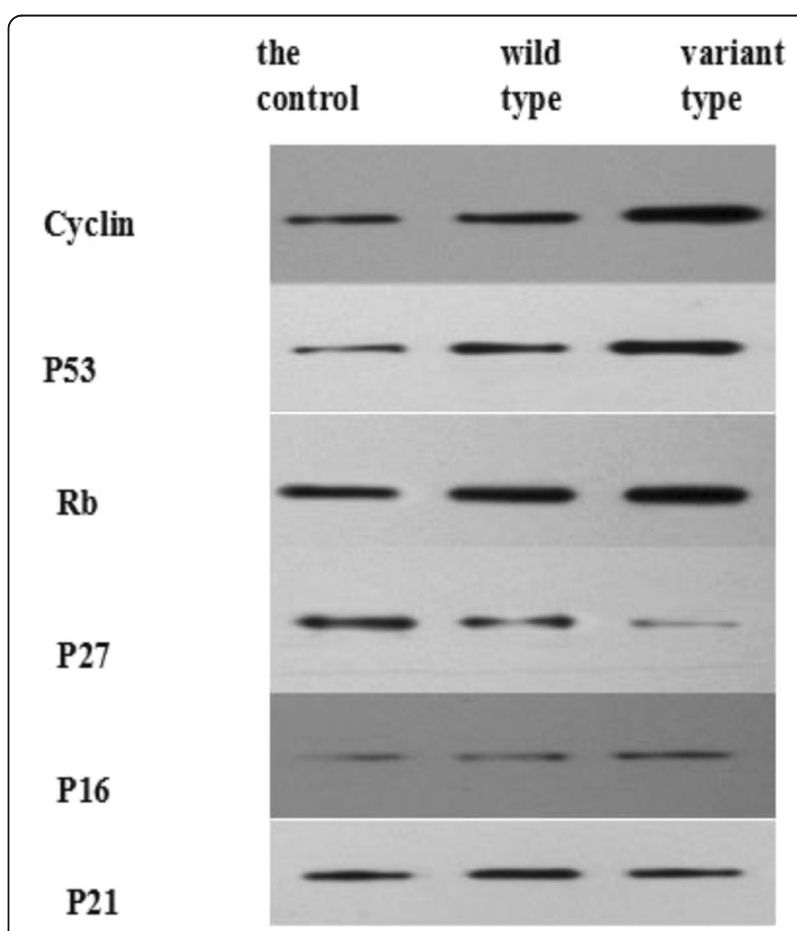

Fig. 1 Detection of Cyclin D1、p53、P16、P27、P21 and Rb protein expression by Western blot 
3.132, P all <0.05) and P27 mRNA in variant type group was significantly downregulated (t was $8.363, P<0.05$ ). There was no statistical significance between wild type group and control group $(P>0.05)$. P16 and P21 expression showed no statistical sigtfificance in any of these three groups $(P>0.05)$. (Table 2$)$.

\section{Discussion}

Recent genome-wide association studies have identified that variant in TM6SF2 was significantly associated with liver dieases in multiple ethnic groups. Some studies assessed the interaction between TM6SF2 E167K variant in the conditioning of HCC development had come to the conclusion that TM6SF2 E167K variant may be potential genetic risk factors for developing HCC [11-13]. Our study was to explore the cell cycle of HEPA 1-6 cells affected by E167K polymorphism of TM6SF2 gene and the possible mechanisms.

Eukaryotic DNA replication is regulated to ensure all chromosomes replicate once and only once per cell cycle [14]. Errors that result in underreplication or overeplication of the genome in any cell cycle have disastrous consequences and can produce a large array of human genetic diseases, including cancer, birth defects, and many developmental abnormalities [15]. Cell cycle included $G_{1}, S, G_{2}$ and $M$ phases. $G_{1} / S$ phase and $G_{2} / M$ phase were the important "Check" for cell cycle and were to maintain the normal operation of the cell cycle. Cell cycle regulation by protein phosphorylation ensures that pre-RC assembly can only occur in $G_{1}$ phase, whereas helicase activation and loading can only occur in $S$ phase [14]. Once the cell passed through the $G_{1} / S$ phase, it will no longer depend on the exogenous proliferation and division signal and complete cell cycle independently [14]. Therefore, the $G_{1} / S$ phase is the most critical period of cell cycle regulation. In our study, $G_{1}$ phase was significantly decreased and $S$ phase and $G_{2} / M$ phase were increased in variant type group than wild type group and the control group. The result suggested that TM6SF2 gene mutation of E167K may promote DNA replication and accelerate cell cycle of human hepatocellular carcinoma cell line HEPA 1-6 and thereby promote the development of liver cancer cells. Therefore, the acceleration of cell cycle may has the important influence in malignant progression of HCC cells.

Cell cycle regulation is a hot topic in the field of oncology and it is a very complex and delicate process. A variety of internal and external factors involved in the process of cell cycle regulation. These factors included cells cyclin (cyclin), cyclin dependent-kinase (CDK) and some tumor suppressor genes such as Rb, p16, p21, p27, p53 protein products $[16,17]$. A large number of studies have showed that cyclin, Rb, p16, p21, p27 and p53 played an important role in $G_{1} / S$ phase of cell cycle [18-22]. Uncontrolled cell proliferation is the hallmark of cancer, and tumor cells have typically acquired damage to genes that directly regulate their cell cycles [23]. In our study, our results showed that CyclinD1、P53 and $\mathrm{Rb}$ were increased and P27 was decreased in variant type group, which suggested that E167K polymorphism of TM6SF2 gene may change the cell cycle of hepatocellular carcinoma cell HEPA 1-6 through up-regulatating CyclinD1、P53 and Rb and downregulatating P27.

\section{Conclusions}

In conclusion, this study elucidated that E167K polymorphism of TM6SF2 gene can affect cell cycles of HEPA1-6 cells and the possible mechanisms may upregulate CyclinD1、 P53 and $\mathrm{Rb}$ and down-regulate P27. Cell cycle disorder further promoted the deterioration of cell energy metabolism, which thereby formed the vicious cycle to promote progression of HCC.

Table 2 Detection of Cyclin D1、p53、P16、P27、P21 and Rb mRNA expression by Quantitative Real Time PCR

\begin{tabular}{|c|c|c|c|c|c|c|}
\hline \multirow[t]{2}{*}{ groups } & \multicolumn{6}{|c|}{ Quantitative Real Time PCR } \\
\hline & Cyclin D1 & $\mathrm{p} 53$ & $\mathrm{Rb}$ & P27 & P21 & P16 \\
\hline variant type group & $2.03 \pm 0.01$ & $1.88 \pm 0.05$ & $1.29 \pm 0.06$ & $0.56 \pm 0.02$ & $0.78 \pm 0.06$ & $1.00 \pm 0.04$ \\
\hline wild type group & $1.00 \pm 0.00$ & $1.48 \pm 0.09$ & $1.18 \pm 0.01$ & $0.82 \pm 0.05$ & $0.77 \pm 0.02$ & $1.01 \pm 0.06$ \\
\hline the control group & $1.04 \pm 0.06$ & $1.37 \pm 0.03$ & $1.15 \pm 0.03$ & $0.85 \pm 0.05$ & $0.78 \pm 0.04$ & $1.00 \pm 0.06$ \\
\hline $\mathrm{t} 1$ & 178.532 & 6.729 & 3.132 & 8.363 & 0.158 & 0.240 \\
\hline P1 & $<0.001$ & 0.0016 & 0.041 & $<0.001$ & $>0.05$ & $>0.05$ \\
\hline t2 & 28.190 & 15.152 & 3.615 & 9.328 & 0 & 0 \\
\hline P2 & $<0.001$ & $<0.001$ & 0.014 & $<0.001$ & $>0.05$ & $>0.05$ \\
\hline t3 & 1.156 & 2.008 & 1.643 & 0.735 & 0.387 & 0.204 \\
\hline P3 & $>0.05$ & $>0.05$ & $>0.05$ & $>0.05$ & $>0.05$ & $>0.05$ \\
\hline
\end{tabular}

t1:between variant type group and wild type group; t2:between variant type group and the control group; t3:between wild type group and the control group; 


\section{Abbreviations}

CDK: Cyclin dependent-kinase; Cyclin: Cells cyclin; HCC: Hepatocellular carcinoma cell; PCR: Polymerase chain reaction; RT-PCR: Real time-polymerase chain reaction; TM6SF2: The transmembrane 6 superfamily member 2

\section{Acknowledgements}

We thank Qingdao Medical University, Qingdao Municipal Hospital, Digestive Disease Key Laboratory of Qingdao and all the participants in the our study.

\section{Funding}

This study was supported by the Key Research Project of Shandong Province (2016GSF201217)、Medical and Health Technology Development Project of Shandong Province (2015WS0321)、Qingdao, Shinan District Science and Technology Development Project Fund (2015-6-014-YY、2016-3-016-YY).

\section{Availability of data and materials}

No.

\section{Authors' contributions}

Study concept and design: SXD, LLL. acquisition of the data: SXD, YXM. analysis and interpretation of the data: SXD, CFL. drafting of the manuscript: SXD, LLL. critical revision of the manuscript for important intellectual content: SYX, YNX. statistical analysis: SXD, WWJ, LLL. administrative technical and material support: YNX. supervision: SYX,YNX. All authors read and approved the final manuscript.

\section{Competing interests}

The authors declare that they have no competing interests

\section{Consent for publication}

No.

\section{Ethics approval and consent to participate}

This study was approved by the ethics committee on human research of Qingdao municipal hospital (Qingdao, China). This study was performed in accordance with the principles of the declaration of Helsinki and its appendices [24].

\section{Publisher's Note}

Springer Nature remains neutral with regard to jurisdictional claims in published maps and institutional affiliations.

\author{
Author details \\ ${ }^{1}$ Medical College of Qingdao University, Qingdao 266071, China. \\ ${ }^{2}$ Department of Gastroenterology, Qingdao Municipal Hospital, 1 Jiaozhou \\ Road, Qingdao, Shandong Province 266011, China. ${ }^{3}$ Digestive Disease Key \\ Laboratory of Qingdao, Qingdao 266071, China.
}

Received: 27 February 2017 Accepted: 4 April 2017

Published online: 13 April 2017

\section{References}

1. Hayles J, Wood V, Jeffery L, Hoe KL, Kim DU, Park HO, et al. A genome-wide resource of cell cycle and cell shape genes of fission yeast. Open Biol. 2013; 3(5):130053.

2. Evan $\mathrm{Gl}$, Vousden $\mathrm{KH}$. Proliferation, cell cycle and apoptosis in cancer. Nature. 2001;411(6835):342-8

3. Brown JS, O'Carrigan $B$, Jackson SP, Yap TA. Targeting DNA repair in cancer: beyond PARP inhibitors. Cancer Discov. 2017;7(1):20-37.

4. Schmitt AM, Garcia JT, Hung T, Flynn RA, Shen Y, Qu K, et al. An inducible long noncoding RNA amplifies DNA damage signaling. Nat Genet. 2016; 48(11):1370-6.

5. Chen LZ, Xia H-X, Xin YN, Lin ZH, Xuan SY. TM6SF2 E167K variant, a novel genetic susceptibility variant, contributing to nonalcoholic fatty liver disease. J Clin Transl Hepatol. 2015:3(4):265-70.

6. Eslam M, Mangia A, Berg T, Chan HL, Irving WL, Dore GJ, et al. Diverse impacts of the rs58542926 E167K variant in TM6SF2 on viral and metabolic liver disease phenotypes. Hepatology. 2016;64(1):34-46.

7. Scorletti E, West AL, Bhatia L, Hoile SP, McCormick KG, Burdge GC, et al. Treating liver fat and serum triglyceride levels in NAFLD, effects of PNPLA3 and TM6SF2 genotypes: results from the WELCOME trial. J Hepatol. 2015; 63(6):1476-83.

8. Wainwright $P$, Byrne $C D$. Bidirectional relationships and disconnects between NAFLD and features of the metabolic syndrome. Int J Mol Sci. 2016;17(3):367.

9. Yki-Järvinen H. Diagnosis of non-alcoholic fatty liver disease (NAFLD). Diabetologia. 2016;59(6):1104-11.

10. Livak KJ, Schmittgen TD. Analysis of relative gene expression data using real-time quantitative PCR and the 2(-Delta Delta $C(T)$ ) method. Methods. 2001;25:402-8

11. Falleti E, Cussigh A, Cmet S, Fabris C, Toniutto P. PNPLA3 rs738409 and TM6SF2 rs58542926 variants increase the risk of hepatocellular carcinoma in alcoholic cirrhosis. Dig Liver Dis. 2016;48(1):69-75.

12. Thabet K, Chan HL, Petta S, Mangia A, Berg T, Boonstra A. The MBOAT7 variant rs641738 increases inflammation and fibrosis in chronic hepatitis B. Hepatology. 2017; doi:10.1002/hep.29064.

13. Dongiovanni $P$, Valenti L. Genetics of nonalcoholic fatty liver disease. Metabolism. 2016:65(8):1026-37.

14. Sclafani RA, Holzen TM. Cell cycle regulation of DNA replication. Annu Rev Genet. 2007:41:237-80.

15. Depamphilis ML. DNA replication and human disease. Cold Spring Harbor Laboratory Press. 2006:9(4):356.

16. Xie Z, Tan G, Ding M, et al. Foxm1 transcription factor is required for maintenance of pluripotency of P19 embryonal carcinoma cells. Nucleic Acids Res. 2010;38(22):8027-38.

17. Tan $Y$, Xie $Z$, Ding $M$, et al. Increased levels of FoxA1 transcription factor in pluripotent P19 embryonal carcinoma cells stimulate neural differentiation. Stem Cells Dev. 2010;19(9):1365-74.

18. Nazim UM, Md R, Lee YJ, Seol DW, Park SY. Enhancement of TRAlL-induced apoptosis by 5-fluorouracil requires activating Bax and p53 pathways in TRAlL-resistant lung cancers. Oncotarget. 2017:8:18095-105.

19. Xie X, Shi X, Guan H, Guo Q, Fan C, Dong W, et al. P21-activated kinase 4 involves TSH induced papillary thyroid cancer cell proliferation. Oncotarget. 2017;8:24882891.

20. Crockford A, Zalmas LP, Grönroos E, Dewhurst SM, McGranahan N, Cuomo $M E$, et al. Cyclin D mediates tolerance of genome-doubling in cancers with functional p53. Ann Oncol. 2017:28(1):149-56.

21. Saito Y, Ushiku T, Omura G, Yasuhara K, Yoshida M, Takahashi W, et al. Clinical value of the Epstein-Barr virus and p16 status in patients with nasopharyngeal carcinoma: a single-Centre study in Japan. ORL J Otorhinolaryngol Relat Spec. 2017;78(6):334-43.

22. Lee Jl, Kim IH, Nam TJ. Crude extract and solvent fractions of Calystegia soldanella induce G1 and S phase arrest of the cell cycle in HepG2 cells. Int J Oncol. 2017:50(2):414-20.

23. Sherr CJ. Cancer cell cycles. Science. 1996;274(5293):1672-7.

24. Rickham PP. Human experimentation. Code of ethics of the world Medical association. Declaration of Helsinki. Br Med J. 1964;2(5402):177.

\section{Submit your next manuscript to BioMed Central} and we will help you at every step:

- We accept pre-submission inquiries

- Our selector tool helps you to find the most relevant journal

- We provide round the clock customer support

- Convenient online submission

- Thorough peer review

- Inclusion in PubMed and all major indexing services

- Maximum visibility for your research

Submit your manuscript at www.biomedcentral.com/submit
Biomed Central 